\title{
Normal serum activities of liver enzymes in Swedish paint industry workers with heavy exposure to organic solvents
}

\section{LUNDBERG ${ }^{12}$ AND MARIANNE HÅKANSSON'}

From the Section of Occupational Medicine ${ }^{1}$ and Unit of Occupational Toxicology, ${ }^{2}$ Research Department, National Board of Occupational Safety and Health, S-171 84 Solna, Sweden

ABSTRACT The serum activities of the liver enzymes alanine aminotransferase, aspartate aminotransferase, ornithine carbamyl transferase, and $\gamma$-glutamyl transferase were examined in 47 paint $\frac{1}{0}$ industry workers and unexposed age matched referents. The workers were exposed to a mixture if of industrial solvents, of which xylene was the main component in most cases. The median total $\mathscr{\odot}$ exposure was about $50 \%$ of Swedish 1981 threshold limit values according to measurements of 은 individual solvent exposure performed at the same time. No differences in enzyme activities were $\overrightarrow{c \rho}$ shown either when the whole exposed and referent groups were compared or when the five $\mathbb{D}$ workers with outstanding solvent exposures of five times the TLV or more were compared with $\frac{\vec{D}}{\mathbb{D}}$ their referents. It is concluded that in most workers the liver seems to remain largely undamaged 3 from inhalation exposure to a commonly used mixture of non-chlorinated solvents. In many $\stackrel{\mathbb{Q}}{-}$ workers this seems to hold true even for high exposures for limited periods.

Some solvents-for example, carbon tetrachloride, chloroform, 1,2-dichloroethane, and 1,1,2,2tetrachloroethane-are metabolically activated and damage the liver in man as well as in animals. Isopropyl alcohol, acetone, and ethyl alcohol enhance the hepatotoxicity of such solvents in rats, ${ }^{12}$ perhaps through an increased formation of toxic solvent metabolites resulting from the induction of microsomal enzymes.

Many solvents are considered potentially hepatotoxic, singly or in combination with ethanol or other substances, and therefore serum activities of liver enzymes have often been determined in periodic examinations of workers exposed to solvents. Nevertheless, as shown by Kurppa and Husman and others, painters and car painters exposed to mixed solvents ${ }^{34}$ and workers exposed to toluene ${ }^{56}$ do not have higher serum levels of liver enzyme activity than unexposed referents. These results have been challenged by the studies of Sotaniemi $e t$ $a l$ and Dössing $e t a^{78}$ but the relation between solvent exposure and liver damage in these studies cannot be considered causal owing to lack of adequ-

Received 5 November 1984

Accepted 26 November 1984 ate control groups. ${ }^{9}$ In other cases the reason for the detection of raised serum activities might be the presence of proved hepatotoxic substances in the sol-o vent mixture. ${ }^{10}$

Recent case reports have suggested an association $\stackrel{\AA}{\AA}$ between concomitant solvent exposure and drug $\overrightarrow{\overrightarrow{\vec{A}}}$ intake and raised serum activities of liver enzymes 3 and fatty change in the liver. ${ }^{11}$

No studies known to us provide individual expos-? ure data and information concerning possible exposure-response relations. In the present paper $\stackrel{\mathbb{\Phi}}{3}$ we report on enzyme measurements in Swedish paint industry workers for whom individual expos- 3 . ure was also determined. Some of the workers were exposed to extremely high air solvent concentra- 3 tions.

\section{Material and methods}

SUBJECTS

Forty seven employees from seven different paint industries in various parts of southern Sweden took part in the study. The participants were selected according to two criteria:

(1) Exposure to solvents in a paint industry fof을 more than 10 years. This group consisted of 33 men and five women, median age 57 (range 27-64); or 
Table 1 Detected solvents and their threshold limit values (TLVs), number of workers exposed to each solvent, median exposure values for those exposed, and exposure ranges. (All exposure figures are expressed as 8-h time weighted averages)

\begin{tabular}{|c|c|c|c|c|}
\hline Solvent & No exposed & $\begin{array}{l}\text { Median exposure } \\
\left(m g / m^{3}\right)\end{array}$ & $\begin{array}{l}\text { Exposure range } \\
\left(\mathrm{mg} / \mathrm{m}^{3}\right)\end{array}$ & $T L V\left(m g / m^{3}\right)$ \\
\hline $\begin{array}{l}\text { Xylene } \\
\text { Toluene } \\
\text { Isobutanol } \\
\text { n-Butanol } \\
\text { Ethanol } \\
\text { Ethylacetate } \\
\text { n-Butylacetate } \\
\text { White spirit } \\
\text { Methylacetate } \\
\text { Methylene chloride } \\
\text { Methylethylketone } \\
\text { Isopropanol }\end{array}$ & $\begin{array}{r}44 \\
43 \\
36 \\
35 \\
33 \\
32 \\
31 \\
18 \\
11 \\
5 \\
5 \\
3\end{array}$ & $\begin{array}{r}82 \\
10 \\
4 \\
6 \\
12 \\
26 \\
9 \\
44 \\
13 \\
719 \\
39 \\
129\end{array}$ & $\begin{array}{l}1-6070 \\
1-1260 \\
1-1040 \\
1-1540 \\
1-1090 \\
1-767 \\
1-1680 \\
5-74 \\
3-169 \\
10-2420 \\
8-124 \\
6-258\end{array}$ & $\begin{array}{r}350 \\
300 \\
150 \\
150 \\
1900 \\
700 \\
700 \\
500 \\
600 \\
250 \\
300 \\
500\end{array}$ \\
\hline
\end{tabular}

(2) Exposure to solvents during the manual cleaning of paint mixing equipment regardless of duration of employment. This group consisted of nine men, median age 47 (range 20-58).

An unexposed referent, matched by age (within three years), sex, and place of residence was chosen for every exposed subject. All the referents were unskilled blue collar workers. The participants were interviewed with standardised questionnaires about alcohol consumption, use of drugs, and experience of liver disease of any sort.

The median value of the stated alcohol consumption was $48 \mathrm{~g}$ alcohol/week in the exposed and $32 \mathrm{~g}$ alcohol/week in the referent group after conversion of different beverages to $100 \%$ alcohol. The use of medicines was similar in the two groups. Ten people in the exposed and 12 in the referent group had taken some sort of drug at least three times a week for the past three weeks and were defined as drug consumers. The drugs were mainly antihypertensive agents, beta-blockers, and thiazide diuretics. Seven of those in the exposed and five in the referent group had a history of acute hepatitis. They had all been diagnosed before 1950, and their serum enzyme activities have been included in the analysis as they did not differ from those of the remainder of their respective groups.

Table 2 Solvents measured concomitantly in the breathing zone of the five workers with the highest exposures

\begin{tabular}{llll}
\hline Solvent & No exposed & $\begin{array}{l}\text { Median } \\
\text { exposure } \\
\left(\mathrm{mg} / \mathrm{m}^{3}\right)\end{array}$ & $\begin{array}{l}\text { Exposure range } \\
\left(\mathrm{mg} / \mathrm{m}^{3}\right)\end{array}$ \\
\hline Xylene & 5 & 865 & $501-6070$ \\
Toluene & 5 & 181 & $111-1260$ \\
Isobutanol & 5 & 135 & $69-1040$ \\
n-Butanol & 5 & 35 & $14-354$ \\
n-Butylacetate & 5 & 212 & $104-1680$ \\
Ethanol & 5 & 191 & $119-1090$ \\
Ethylacetate & 5 & 97 & $14-221$ \\
Methylene chloride & 4 & 804 & $635-2420$ \\
Methylacetate & 4 & 57 & $19-169$ \\
\hline
\end{tabular}

No systematic selection of workers away from solvent exposed tasks had occurred as the result of clinical or biochemical signs of liver damage.

\section{EXPOSURE}

Air from the breathing zone of each exposed subject was collected with battery driven syringes, each representing about 30 minutes of exposure during a complete workday. The contents of the syringes were analysed with two AID portable gas chromatographs with flame ionisation detectors. Steel columns were used (length $2 \mathrm{~m}$, internal diameter $0.32 \mathrm{~cm}$ ), packed with Chromosorb $\mathrm{C}$ (60-80 mesh) coated with $2 \%$ Carbowax 400 or Chromosorb WHP (80-100 mesh) coated with $10 \%$ DC 200. The column temperatures were $60^{\circ}$ and $100^{\circ} \mathrm{C}$ respectively.

Twelve different solvents were identified in the air. They are listed in table 1 together with the numbers exposed to each, the median exposure values, and the exposure ranges. All exposure figures are expressed as 8-h time weighted averages (TWA); the 1981 Swedish threshold limit values (TLV) are included for comparison.

The workers were each exposed to between three and nine (median 7) solvents. Table 1 shows that in most cases the main exposure was to xylene or toluene, or both, representing more than $50 \%$ of the total solvent exposure on a weight basis in 31 cases. In 20 cases xylene alone accounted for more than $50 \%$ of the total exposure.

The hygienic effect ${ }^{*}$ was used as a measure of total solvent exposure. The median value of the 8-h TWA hygienic effect was $0 \cdot 5$ (range $0 \cdot 1-47$ ).

The solvent exposure of five workers with outstanding exposures (median 8-h TWA hygienic effect $8 \cdot 4$, range 5.4-47) during the manual cleaning of equipment is presented in table 2 . The other

\footnotetext{
* The hygienic effect is defined as the sum of the fraction of the respective TLV that each solvent represents.
} 
Table 3 Serum activities of liver enzymes ( $\mu$ kat/l) among paint industry workers and referents

\begin{tabular}{llllll}
\hline Enzyme & \multicolumn{2}{l}{ Exposed } & \multicolumn{2}{l}{ Referents } \\
\cline { 2 - 3 } \cline { 5 - 6 } & Mean & $S D$ & & Mean & $S D$ \\
\hline ASAT & 0.38 & 0.10 & & 0.40 & 0.14 \\
ALAT & 0.35 & 0.16 & & 0.43 & 0.36 \\
GT & 0.45 & 0.54 & & 0.41 & 0.26 \\
OCT & 0.15 & 0.05 & & 0.15 & 0.06 \\
\hline
\end{tabular}

ASAT $=$ Aspartate aminotransferase

ALAT = Alanine aminotransferase.

GT $=\gamma$-glutamyltransferase .

OCT $=$ Ornithine carbamyl transferase

cleaners were exposed to 8-h TWA hygienic effects of less than $2 \cdot 0$, and none was exposed to a hygienic effect greater than $2 \cdot 4$. Personal protection was hardly ever used, even among the most heavily exposed, and did not reduce uptake significantly.

\section{LABORATORY TESTS}

The blood samples, from both exposed and referents, were obtained from the cubital vein in the morning before work on Tuesday, Wednesday, or Thursday, the same day as the exposure measurements were performed. The serum was put into a freezer within two hours of the sample being obtained and was kept frozen at $-20^{\circ} \mathrm{C}$ until it was analysed.

The activities of the following enzymes were measured: aspartate aminotransferase (ASAT), alanine amonitransferase (ALAT), $\gamma$ glutamyltransferase (GT) and ornithine carbamyl transferase (OCT). The first three enzymes were analysed according to conventional methods, ${ }^{12} 13$ OCT was analysed with a method described by Ceriotti ${ }^{14}$; ASAT and ALAT were analysed within 10 , and GT and OCT within 20 days after blood collection.

The methods for the analysis of ASAT, ALAT, and GT were controlled with Seronorm, for which activities of these enzymes are given. The coefficients of variation in these analyses were less than 3.4. As there is no recommended value for OCT in the analytical data for Seronorm, the OCT value was established by analyses made before the Seronorm batch was used to control the analyses of the serum of the paint industry workers. The coefficient of variation in these analyses was $8 \cdot 3$.

\section{STATISTICAL METHODS}

Differences in enzyme activities of the matched pairs were analysed with Wilcoxon's rank sum test for paired differences; for group differences, Wilcoxon's rank sum test was used. The relation between enzyme activities and other variables were studied with multiple regression analysis. The dif-
Table 4 Serum GT activities ( $\mu$ kat/l) among exposed workers and referents with and without medication

\begin{tabular}{|c|c|c|c|c|}
\hline & \multicolumn{2}{|c|}{ With medication } & \multicolumn{2}{|c|}{ Without medication } \\
\hline & Mean & $S D$ & Mean & $S D$ \\
\hline $\begin{array}{l}\text { Exposed } \\
\text { Referents }\end{array}$ & $\begin{array}{l}0.60 \\
0.59\end{array}$ & $\begin{array}{l}0.71 \\
0.41\end{array}$ & $\begin{array}{l}0.41 \\
0.34\end{array}$ & $\begin{array}{l}0.49 \\
0.14\end{array}$ \\
\hline
\end{tabular}

ferences and the correlations were regarded as statistically significant if the two tailed $p$ value was $<0.05$.

\section{Results}

The mean values of the enzyme activities in the $\frac{\mathbb{}}{3}$ exposed and referent groups were similar and there were no statistical differences between the groups ${ }_{0}^{N}$ (table 3). The standard deviations were sometimes in large owing to the inclusion of a few individuals with 8 clearly pathological levels at the time of the study. 우 The number of pathological levels (outside the mean in the referent group +2 SD) were, however, simi- $\infty$ D lar in both groups.

The enzyme levels were not significantly related $\frac{\mathbb{\Phi}}{3}$ to stated alcohol consumption in the two groups, nor could enzyme activities be related to the exposure $\stackrel{\mathbb{Q}}{?}$ levels of any of the solvents alone or to any combi- $\vec{\oplus}$ nation of solvents or to the total solvent exposufe or calculated as the hygienic effect. Even comparisons between possible combinations of extremes concer ing stated alcohol consumption and exposure (high stated alcohol intake and high exposure versus low stated alcohol intake and no exposure; high stated $\frac{\mathcal{Q}}{\Phi}$ alcohol consumption and high exposure versus high $\stackrel{\circ}{\Rightarrow}$ stated alcohol consumption and low exposure, for example) showed no effect on serum enzyme activities due to exposure. Drug consumers showed significantly higher GT-activities than nonconsumers in the exposed and referent groups (table 4). The median 8-h TWA solvent exposure hygienic 3 effect was 0.4 in the exposed drug consumers, simi-욱 lar to the overall average exposure. There were no. differences in any enzyme activities betweenô exposed and referent workers after stratification for 2

Table 5 Serum activities of liver enzymes ( $\mu$ kat/l) among the five most exposed paint industry workers and their referents

\begin{tabular}{|c|c|c|c|c|}
\hline \multirow[t]{2}{*}{ Enzyme } & \multicolumn{2}{|c|}{ Exposed } & \multicolumn{2}{|c|}{ Referents } \\
\hline & Mean & $S D$ & Mean & $S D$ \\
\hline $\begin{array}{l}\text { ASAT } \\
\text { ALAT } \\
\text { GT } \\
\text { OCT }\end{array}$ & $\begin{array}{l}0.31 \\
0.23 \\
0.24 \\
0.14\end{array}$ & $\begin{array}{l}0.05 \\
0.08 \\
0.04 \\
0.02\end{array}$ & $\begin{array}{l}0.38 \\
0.36 \\
0.35 \\
0.14\end{array}$ & $\begin{array}{l}0.08 \\
0.14 \\
0.19 \\
0.01\end{array}$ \\
\hline
\end{tabular}

Enzymes: see table 3. 
use of medication, and workers on medication with high exposure did not show an increase in serum enzyme activities.

The five "cleaners" (median employment duration 0.8 years, range $0 \cdot 2-4$ ) with outstanding solvent exposures described in table 2 showed numerically lower ASAT, ALAT, and GT activities than their referents (table 5), although the differences were not statistically significant. There were no subjects on medication in any of the subgroups, and the stated alcohol consumption was similar.

\section{Discussion}

The results of this investigation agree with those of several other investigators. ${ }^{3-6}$ The exposure levels in our study were, in some cases, much higher and the main component of the solvent mixture was xylene whereas toluene dominated in the solvent mixture studied by Kurppa and Husman. ${ }^{4}$

An increase in serum GT as a somewhat unreliable marker for microsomal enzyme induction, ${ }^{15}$ might have been expected in the cleaners, the group with the highest exposure. $\mathrm{m}$-Xylene, for example, increases the activity of liver microsomal enzymes in rats after five days of exposure to $1730 \mathrm{mg} / \mathrm{m}^{3}$, six hours a day. ${ }^{16}$ Dössing, however, has shown that spray painters exposed to a solvent mixture similar to that of the paint industry workers in fact had inhibited microsomal enzymes as measured by antipyrine clearance. ${ }^{17}$ According to our own observations and those of the staff of the industries, the solvent exposure of the cleaners was not unusual on the day of measurement. Earlier exposure measurements $^{18}$ have also recorded extremely high exposures among cleaners.

Statements concerning alcohol consumption are known to be unreliable and this might explain the lack of correlation with serum enzyme activities. The median stated consumption was low in both groups, however, and the subjects admitting the highest consumption, about 300 and $220 \mathrm{~g}$ a week in the exposed and referent groups, respectively, showed enzyme activities close to the mean values of their groups. Thus in both groups alcohol consumption might have been so low that it did not affect the liver enzymes.

The medication used by different participants in this study is known to raise serum GT activities only rarely (E Steiner, G Alvan, personal communication) but another study ${ }^{19}$ has shown higher serum GT activities among hypertensive men compared with men with normal blood pressure. Higher alcohol consumption among the hypertensive men was suggested as an explanation but there is no such correlation in our material. Furthermore there does not seem to be any interaction between the medication used and an exposure to 0.4 as median $8-\mathrm{h}$ TWA hygienic effect of the solvent mixture found in the paint industries.

Our study supports the view that, in most workers, the liver remains largely undamaged by exposure to commonly occurring mixtures of predominantly non-chlorinated solvents. This seems to hold true even for high levels of exposure levels for limited periods.

We thank engineers I-M Andersson and G Rosen who performed the exposure measurements and laboratory assistants E Fredriksson, M Holmkvist, A Pehrsson, C Wahlberg, and R Eriksson who performed the enzyme analyses. We are grateful to Professors $\AA$ Swensson and U Ulfvarson who initiated the study and to Professor C Hogstedt for comments on the manuscript. This study was part of a research programme on exposure and health hazards in the paint industry financed by the Swedish Work Environment Fund.

\section{References}

' Cornish H, Adefuin J. Ethanol potentiation of halogenated aliphatic solvent toxicity. Am Ind Hyg Assoc J 1966;27:57-61.

${ }^{2}$ Traiger G, Plaa G. Chlorinated hydrocarbon toxicity: potentiation by isopropyl alcohol and acetone. Arch Environ Health 1974;28:276-8.

${ }^{3}$ Kurppa K, Husman K. Car painters exposure to a mixture of organic solvents. Serum activities of liver enzymes. Scand $J$ Work Environ Health 1982;8:137-40.

4 Hane M, Axelson O, Blume J, Hogstedt C, Sundell L, Ydreborg B. Psychological function changes among house painters. Scand J Work Environ Health 1977;3:91-9.

s Tähti H, Kärkkäinen S, Pyykkö K, Rintala E, Kataja M, Vapaatalo $\mathrm{H}$. Chronic occupational exposure to toluene. Int Arch Occup Environ Health 1981;48:61-9.

- Waldron HA, Cherry N, Venables H. Solvent exposure and liver function. Lancet 1982;ii: 1276.

' Sotaniemi EA, Sutinen S, Sutinen S, Arranto AJ, Pelkonen RO. Liver injury in subjects occupationally exposed to chemicals in low doses. Acta Med Scand 1982;212:207-15.

8 Dössing M, Arlien-Söborg P, Milling Petersen L, Ranek L. Liver damage associated with occupational exposure to organic solvents in house painters. Eur J Clin Invest 1983;13:151-7.

' Kurppa K, Tola S, Hernberg S, Tolonen M. Industrial solvents and the liver. Lancet 1983;i: 129.

${ }^{10}$ Fischbein A, Ross RR, Lerman Y. Industrial solvents and the liver. Lancet 1983; i: 129.

"Edling C. Interaction between drugs and solvents as a cause of fatty change in the liver? $\mathrm{Br} J$ Ind Med 1982;39:198-9.

12 Committee on Enzymes of the Scandinavian Society for Clinical Chemistry and Clinical Physiology. Recommended methods for the determination of four enzymes in blood. Scand J Clin Lab Invest 1974;33:291-306.

${ }^{13}$ Committee on Enzymes of the Scandinavian Society for Clinical Chemistry and Clinical Physiology. Recommended method for the determination of gamma glutamyl transferase in blood. Scand J Clin Lab Invest 1976;36:121-5. 
14 Ceriotti G. Optimal conditions for ornithine carbamyl transferase determination. A simple micromethod without deproteinization. Clin Chim Acta 1973;47:97-105.

${ }^{15}$ Goldberg D. The expanding role of microsomal enzyme induction, and its implications for clinical chemistry. Clin Chem 1980;26:691-9.

${ }^{16}$ Elovaara E. Dose-related effects of $m$-xylene inhalation on the xenobiotic metabolism of the rat. Xenobiotica 1982;12:34552.

1 Dössing M. Changes in hepatic microsomal enzyme function in workers exposed to mixtures of chemicals. Clin Pharmacol Ther 1982;32:340-6.

${ }^{18}$ Ulfvarson U. Chemical hazards in the paint industry. In: International symposium on the control of air pollution in the working? environment. Stockholm: Work Environment Fund, 1977:66-75.

${ }^{19}$ Henningsen NC, Ohlsson O, Mattiasson I, Trell E, Kristensson H, Hood B. Hypertension, levels of serum gamma glutamyl transpeptidase and degree of blood pressure control in middle-aged males. Acta Med Scand 1980;207:245-51.

\section{Correspondence and editorials}

The British Journal of Industrial Medicine welcomes correspondence relating to any of the material appearing in the journal. Results from preliminary or small scale studies may also be published in the correspondence column if this seems appropriate. Letters should be not more than $\mathbf{5 0 0}$ words in length and contain a minimum of references. Tables and figures should be kept to an absolute minimum. Letters are accepted on the understanding that they may be subject to editorial revision and shortening.

The journal now also publishes editorials which are normally specially commissioned. The Editor welcomes suggestions regarding suitable topics; those wishing to submit an editorial, however, should do so only after discussion with the Editor. 